\title{
The Fabric of Academic Communities at the Heart of the British Empire's Modernization Policies
}

\author{
Hélène Charton
}

This chapter underscores the role played by university reforms on the new social and political agenda of the British Empire in the 1940s. The creation of colonial universities in Africa and the multiplying number of scholarships to study in Great Britain that were offered to colonial people, were at the heart of post-war modernization policies. Indeed, the modalities of training a modern educated elite shed light on the nature and range of new links that the home country intended to forge with its African colonies. While the colonial order was based on racial distinctions, the new imperial paradigm, that emerged from the social and political crises of the 1930s, tended to reverse these hierarchies in favor of class relationships, embodied in the new modern elites, sharing a common set of practices and values, entrenched in Great Britain's culture.

The work of American historian Frederick Cooper on the politics of the modernization of empires provides a theoretical framework for this

H. Charton $(\square)$

CNRS, Les Afriques dans le Monde, University of Bordeaux, Bordeaux, France e-mail: h.charton@sciencespobordeaux.fr

(C) The Author(s) 2020

D. Matasci et al. (eds.), Education and Development in Colonial and Postcolonial Africa, Global Histories of Education, https://doi.org/10.1007/978-3-030-27801-4_10 
analysis, which also draws upon the New Imperial History approach to bring forward connections and interactions between colonies and home countries. ${ }^{1}$ A number of scholars have explored the way in which modernization programs have been implemented in various sectors, such as in urban or social policies. ${ }^{2}$ As shown in many chapters of this edited volume, the training of an educated African elite has also been the subject of historical and sociological research, ${ }^{3}$ something that we will examine here, in conjunction with global imperial dynamics, in order to bring out the political dimensions.

Such an approach must allow us to revisit the notion of modernization, in broaching the intertwining social, political, and economic dimensions of this educational engineering. In fact, analysis of the ways these training programs were implemented in East Africa, and in Kenya

${ }^{1}$ Frederick Cooper, Decolonization and African Society: The Labour Question in French and British Africa (Cambridge: Cambridge University Press, 1996); Ann Laura Stoler and Frederick Cooper (eds.), Tensions of Empire: Colonial Cultures in a Bourgeois World (Berkeley: California Press, 1997); Catherine Hall, Cultures of Empire: Colonizers in Britain and the Empire in the Nineteenth and Twentieth Centuries: A Reader (Manchester: Manchester University Press, 2000); Frederick Cooper, Colonialism in Question: Theory, Knowledge, History (Berkeley: University of California Press, 2005); Catherine Hall and Sonya O. Rose (eds.), At Home with the Empire: Metropolitan Culture and the Imperial World (Cambridge: Cambridge University Press, 2006); Hélène Charton, "Produits d'Empires: expériences universitaires coloniales britanniques et françaises en Asie et en Afrique aux XIX ${ }^{\mathrm{e}}$ et XX ${ }^{\mathrm{e}}$ siècles," Outre-Mers, Revue d'histoire 394-395 (2017): 5-13.

${ }^{2}$ Johanna Lewis, Empire State Building: War and Welfare in Kenya 1925-52 (Oxford: James Currey, 2000); Séverine Awenengo Dalberto, Hélène Charton, and Odile Goerg, "Urban Planning, Housing, and the Making of 'Responsible Citizens' in the Late Colonial Period: Dakar, Nairobi, Conakry," in Governing Cities in Africa: Politics and Policies, ed. by Simon Becker and Laurent Fourchard (Cape Town: HSRC Press, 2013), 43-64.

${ }^{3}$ James Anthony Mangan (ed.), Benefits Bestowed, Education and British Imperialism (Manchester: Manchester University Press, 1988); Apollo O. Nwauwa, Imperialism, Academe and Nationalism: Britain and University Education for Africans 1860-1960 (London: Frank Cass, 1997); Katia Leney, Decolonisation, Independence and the Politics of Higher Education in West Africa (London: Edwin Mellen Press, 2003); Joyce Goodman, Gary McCulloch and William Richardson, “'Empires Overseas' and 'Empires at Home' Postcolonial and Transnational Perspectives on Social Change in the History of Education," Paedagogica Historica 45 (2009): 695-706; Pascale Barthélémy, Africaines et diplômées à l'époque coloniale (1918-1957) (Rennes: Presses universitaires de Rennes, 2010); Peter Kallaway and Rebecca Swartz (eds.), Empire and Education: The Shaping of a Comparative Perspective (New York: Peter Lang, 2016); Hélène Charton, "Homo Africanus academicus. Les limites de la fabrique d'une élite universitaire africaine en Afrique de l'Est," Outre-Mers, Revue d'histoire 394-395 (2017): 127-148. 
in particular, reveals the processes of acculturation underpinning these measures, and their obvious political goal. While imperial domination was at that time strongly criticized, these new elites were greatly sought after by emerging powers, such as the Soviet Union, the United States, and India (for detailed case studies, see Chapter 8 by Eric Burton and Chapter 11 by Alexandra Piepiorka, both in this book). ${ }^{4}$ For British authorities, it was a matter of maintaining control over these new elites despite stiff resistance from both colonial administrators, attached to the preservation of a colonial order based on a strict racial differentiation, and African students denouncing the violence of domination.

\section{UNIVERSITIES TO REINVENT THE EMPIRE}

The development of universities in the British colonies and the intensification of training programs in the home country were part of a global project aiming to rebuild the Empire, then facing a major social, economic, and geopolitical crisis.

\section{Establishing New Links Within the Empive}

The British world system emerged severely weakened from the Second World war. In terms of territory, the Empire lost its Asian possessions, and the two great world powers, the United States and the Soviet Union, did not mask their hostility to colonialism. ${ }^{5}$ From the

\footnotetext{
${ }^{4}$ William Roger Louis, "American Anti-colonialism and the Dissolution of the British Empire," International Affairs 61, no. 3 (Summer 1985): 395-420; Hakim Adi, West Africans in Britain 1900-1960, Nationalism, Panafricanism and Communism (London: Lawrence and Wishart, 1998); Hélène Charton, "La genèse ambiguë de l'élite kenyane, origine, formation et intégration, de 1945 à l'indépendance," Ph.D. dissertation, Université Paris 7-Denis Diderot, 2002; Vladimir Bartenev, "L'URSS et l'Afrique noire sous Khrouchtchev: la mise à jour des mythes de la coopération," Outre-mers 354-355 (2007): 63-82; Constantin Kastakioris, “Transferts Est-Sud. Échanges éducatifs et formation de cadres africains en Union soviétique pendant les années soixante," Outre-mers 354-355 (2007): 83-106; Monique de Saint Martin, Grazia Scarfò Ghellab, and Kamal Mellakh (dir.), Étudier à l'Est. Expériences de diplômés africains (Paris: Karthala 2015); Patrice Yengo and Monique de Saint-Martin, “Quelles contributions des élites 'rouges' au façonnement des États post-coloniaux?” Cahiers d'études africaines 226 (2017): 231-258.

${ }^{5}$ Gabriel Olakunle Olusanya, The West African Students Union and the Politics of Decolonization, 1935-1958 (Ibadan: Daystar Press, 1982); Posser Gifford and William Roger Louis (eds.), The Transfer of Power in Africa: Decolonization 1940-1960 (Harvard: Harvard University Press, 1982); Marc Michel, Décolonisations et émergence du
} 
end of the 1930s onward, commissions of inquiry, established after social and political crises in the West Indies and Africa, had brought to light the British colonial model's loss of impetus. In an article published in 1942, following the fall of Singapore, Margery Perham publicly denounced the failure of Great Britain to meet the social and political aspirations of colonial populations but, above all, the violence of colonial racism behind the pauperization of these territories, characterized as "Tropical East Ends." ${ }^{\circ}$ It is in this context that the Labour government of Clement Attlee (1945-1951) attended to the reform of the Empire, in an attempt to save it:

British leaders began to think enthusiastically about the need for imperial unity and a common foreign policy to which Britain, the dominions and the rest of the empire, including India, would be tied.?

This new vision of the British world system confronted the Victorian conception of empire based on a sharp distinction between its former white colonies which had become dominions, and its tropical territories. Erasing this differentiation involved, in fact, the deracialization of the imperial link which found its expression in the redefinition and enlarging of the Commonwealth, from then on conceived as an alliance of nations sharing a history and common economic interests. ${ }^{8}$ The integration of African colonies into the sterling zone was the cornerstone of the reconstruction and restoration of the Empire's prestige. It occurred due to the implementation of voluntarist modernization policies in the economic, social, and political fields.

The Colonial Development and Welfare Act (CDWA), adopted in 1940 and revised in 1945, was the main vehicle of these reforms.

tiers-monde (Paris: Hachette, 1993); Ode Arne Westad, The Global Cold War: Third World Interventions and the Making of Our Times (New York: Cambridge University Press, 2005).

${ }^{6}$ Margery Perham, "The Colonial Empire: Capital, Labour and the Colonial Colour Bar," The Times, 14 March 1942.

${ }^{7}$ John Darwin, The Empire Project: The Rise and Fall of the British World System, 1830 1970 (Cambridge: Cambridge University Press, 2009), 520.

${ }^{8}$ The Commonwealth was created in 1931 around four dominions: New Zealand, South Africa, Canada, and Australia. 
Granted a budget of $£ 100$ million over 10 years, this unprecedented program financed vast modernization projects over a wide range of domains. Education represented 20\% of the budget of the CDWA, much of which was devoted to the creation of colonial universities and to programs offering scholarships in the United Kingdom. These measures aimed to train a qualified workforce, able to occupy senior positions with, in 1945, the still vague and distant prospect of self-government. A memorandum, published in 1946 by the Colonial Office under the title Education for Citizenship, explicitly linked political emancipation with the prior training of colonized people. ${ }^{9}$ Whereas France established a common (but still unequal) citizenship within the newly created Union Française (1946), ${ }^{10}$ the new British imperial strategy was not explicitly political. It rested upon a voluntarist influence policy that could be spread through the building up of new imperial communities sharing a collection of common representations.

The academic communities which arose from post-war training programs were deeply involved in this new political project. The expression "academic community" had been employed in 1912 during the first congress of universities of the British Empire, organized at the University of London on July 2, 1912, to designate its 158 delegates. These British white men (women and the colonized being excluded), had come to celebrate the vitality of British cultural imperialism. Indeed, the universities founded in the former colonies at the end of the nineteenth century were shaped along the same patterns as the homeland institutions with which they maintained close relations (including visiting scholars and student grants). ${ }^{11}$ The establishment of universities in tropical territories reveals the outline of a renewed cultural imperialism that would contribute to rebuilding and fostering the Empire. In fact, the opening up of university training to African people appears a cornerstone of these policies, as colonial people had remained, until that point, at the margins of a solely white imperial history.

\footnotetext{
${ }^{9}$ Public Record Office (PRO), London, CO/859/89/8. Education for Citizenship, 1946.

${ }^{10}$ Frederick Cooper, Citizenship Between Empire and Nation (Princeton: Princeton University Press, 2014).

${ }^{11}$ Tamson Pietsch, Empire of Scholars, Universities, Networks and the British Academic World (1850-1939) (Manchester: Manchester University Press, 2013).
} 
The way in which this African educated elite was trained through post-war modernization programs highlights the features of the new links forged by London with its colonies. It was believed that the promotion of British values, practices, and cultural references in the whole Empire would foster and unite imperial communities that would, in time, overcome dominant racial distinctions in favor of class relations. The processes of acculturation underlying these training arrangements suggest they were part of a broader project aiming to deracialize the Empire.

\section{Training Academic Elites in and for the Colonies}

The Colonial Office started to consider the opportunity of establishing universities in its African colonies in the middle of the 1930s. The project, however, only took shape in 1943, when a commission was established, presided over by Sir Cyril Asquith. Its task was to define a common model of universities for the colonies. ${ }^{12}$ Asquith universities were meant to build bridges between London and its African colonies through the spreading of British university culture. ${ }^{13}$ Thanks to CDWA grants, the first colonial universities were established in Africa after the war. Thus, in West Africa, where education was most developed, the University College of Legon (formerly Achimota), in the Gold Coast, welcomed its first 100 students in 1948. That same year, the University College of Ibadan, in Nigeria, opened its doors to 210 students.

The Inter-University Council, formed with British university representatives, responsible for ensuring the equivalence of diplomas within the Special Relationship Scheme with the University of London, paid its first visit in 1946 to Makerere, Uganda. The Native Technical College of Makerere had been created in 1922 to train African subordinates for colonial administration in the four British territories of East Africa (i.e., Uganda, Tanganyika, Kenya, and Zanzibar) in the fields of health, agriculture, animal husbandry, and education. To become a university, the training college first had to symbolically endorse its new status. When the Inter-University Council visited the college for the second time in

\footnotetext{
${ }^{12}$ Kenya National Archives (KNA), Nairobi, ED/3/3181.

${ }^{13}$ Eric Ashby, British, Indians, African Universities: A Study in the Ecology of Higher Education (London: Weidenfeld \& Nicolson, 1966); John D. Hargreaves, "The Idea of a Colonial University," African Affairs 72 (1973): 26-36.
} 
1949, the school uniforms of shorts, green socks with red bands, and caps with tassels had been replaced by blazers and long trousers. Sport was no longer obligatory and school prefects had disappeared. At a more academic level, three university chairs and two lecturer positions were created; expatriate stipends and adaptable teaching schedules made these positions highly attractive. ${ }^{14}$ In addition, the honorary college member status enabled eminent British professors to regularly visit the college; Margery Perham from Oxford University was one of them. ${ }^{15}$ In 1950, Makerere was able to offer two full-fledged two years' curricula in sciences (higher science) and arts (higher arts), corresponding to the intermediate level of the British bachelor's degree. A $£ 400,000$ CDWA grant for the first five years and $£ 200,000$ for the following five years allowed the college to build new classrooms, science laboratories, and university residences, including one for women only (Mary Stuart Hall), as well as lodgings for academic staff. Thus, between 1948 and 1955, its student body grew from 177 to $558 .^{16}$

Scholarships in the United Kingdom were also awarded to colonial students under the CDWA, for a total of $£ 1$ million over ten years. ${ }^{17}$ African colonies received $41 \%$, with $16 \%$ going to East Africa (a total of $£ 160,000$ of which $£ 43,000$ went to Kenya). ${ }^{18}$ To make sure this program would not hinder the development of colonial universities, applicants were required to have exhausted local educational resources first. Bursaries were first awarded to members of the public service, especially teachers, who would in turn contribute to the modernization project. However, at an average cost of $£ 1500$ per year $(£ 1100$ after the deduction of the salary of the bursar) versus $£ 500$ for Makerere students, the number of scholarships given to one territory remained limited. Thus, between 1946 and 1956, 28 CDWA bursaries were granted to Kenyan students.

${ }^{14}$ Leney, Decolonisation, 94.

${ }^{15}$ Carol Sicherman, Becoming an African University: Makerere 1922-2000 (Trenton: Africa World Press, 2005).

${ }^{16}$ Margaret Macpherson, They Built for the Future: A Chronicle of Makerere College 19221962 (Cambridge: Cambridge University Press, 1964), 47.

${ }^{17}$ PRO, London, WO95/2043. Rules Governing the Award of Scholarships Tenable in the United Kingdom Under the Colonial Development and Welfare Acts, January 1947.

${ }^{18}$ KNA, Nairobi. ED/1/2522, 10 November 1951. 
Colonial governments were also encouraged to finance scholarships from their own budgets with, however, huge discrepancies in the way such programs were administered. Consistent with its segregated educational system, the Government Overseas Bursaries Scheme of Kenya was broken down into three different programs depending on the racial origin of students (Indians, Europeans, and Africans). While four-fifths of the 1948 colony budget, allocated to the higher education of Africans, went to Makerere, African students received only a limited number of scholarships. ${ }^{19}$ In Kenya, only two Africans benefited from this program in 1947 versus 46 in Nigeria. ${ }^{20}$ For the period between 1947 and 1950, 20 Africans were government bursars while there were 38 Europeans and 24 Indians. $^{21}$ Racial discrimination against Kenyan government bursars was the subject of a question raised in Parliament in 1950. The Secretary of State claimed that this situation was due to the weakness of African secondary education in the colony and the limited number of suitable candidates trained in Makerere. ${ }^{22}$ Indeed, African applicants were asked to have completed their studies in Makerere and to have worked for at least two years for government services. They also had to demonstrate that they had insufficient resources to pay for their studies abroad. Such requirements were not raised for European students.

Such racial bias also affected scholarship costs. Married students were given additional stipends to compensate for their loss of salary and allow their wives and families to meet their needs in the colony. According to the common scale issued by the Colonial Office, married students could claim $£ 110$ a year, to which a further $£ 40$ would be added for the first two children, with $£ 27$ added for each subsequent child. The government of Kenya ignored these recommendations, aimed at stopping racial differentiation, and continued to apply its own scales. A European married student's stipend would be, on average, $£ 600$ a year, versus $£ 400$ for an Indian and $£ 60$ for an African. Such racial scales which also applied to salaries, were justified by colonial authorities by quoting discrepancies

${ }^{19} \mathrm{PRO}$, London. CO/533/558/6.

${ }^{20}$ PRO, London. CO/544/61. Kenya Colony and Protectorate, Education Department. Annual Report, 1947.

${ }^{21}$ In total, between 1946 and 1955, the government of Kenya financed scholarships for 38 Africans.

${ }^{22}$ PRO, London. CO/876/133. Parliamentary debates. 
in the living standards and lifestyles of each community. ${ }^{23}$ While Uganda increased its family stipends for African students, Kenya refused on the grounds that Kenyan women were less educated than their neighbors. ${ }^{24}$ In 1953 , the government increased allocations by $50 \%$ but they remained far below those established by London, which had also increased in January 1953. ${ }^{25}$

These examples highlight the inherent contradiction between the objectives of London's modernization programs and the conservatism of colonial administrators and white colonists. While the post-war reforms endeavored to reconfigure the imperial space around its former tropical margins, the emergence of an educated elite acculturated to the British model, at the heart of this new paradigm, presupposed the elimination of racial distinctions. Yet resistance in Kenya made it impossible to overturn these racial hierarchies, dominated by powerful white settlers, on which the colonial order was established. Their hegemony was based on tight control of an educated African elite. This constraint was clearly identified by the newly appointed African representative of the Legislative Council of the colony, who demanded imperial recognition and protection:

Unless Kenya is to be reserved in Africa as a whole as a quarry for museum specimens of ancient Africa, there cannot be any justification in such overdue controls. (...) Africans ought to be trained, not just because one office or institution needs such a one, but for the general welfare of the whole country (...) If we make the future development of Kenya the central theme of our consideration, it is the African students whose backward conditions require them to go for studies overseas, for then assimilation of the Western culture would be ensured. It is the Europeans who have little need to go overseas, for they already have the Western culture in their homes and in their blood (...) We are also British heirs and have a right to claim the best that the Empire can afford for the progress of her peoples. ${ }^{26}$

These training programs precisely sought to develop and bring to life the new imperial academic communities, in encouraging the spread of common values, references, and practices.

\footnotetext{
${ }^{23}$ KNA, Nairobi. ED/3/3165, 19 December 1947.

${ }^{24} \mathrm{KNA}$, Nairobi. ED/1/2297. Report of the liaison officer.

${ }^{25}$ KNA, Nairobi. ED/3/564, 29 July 1953.

${ }^{26}$ KNA, Nairobi. PC/NZA/3/6/162, Owino, 30 June 1945.
} 


\section{The Fabric of Imperial Academic Communities}

\section{The Asquith Universities: Agents of a New Cultural Imperialism}

During the 1950s, Makerere became a university college, hosting an academic community. It adopted codes and practices common to British universities, which contributed to forging the group's collective identity, and to distinguishing it from the rest of the population.

The first official graduation ceremony for those receiving bachelor's degrees in arts and in sciences was organized in Makerere in 1953. For this occasion, five armchairs covered in green leather on which was written the motto of the establishment, that is, Pro futuro aedificamus, ${ }^{27}$ were ordered from England. The choice of Latin, a language not taught in East Africa, but required for entry into Oxford or Cambridge, reveals invisible ties to the British template. The red academic gowns, worn by this first group of graduates, although those of British students were black, reflected the group's distinctiveness, while still attaching it to the larger British academic family. Indeed, exporting to the colonies traditions practiced by prestigious universities, such as Oxford, Cambridge, or Durham, for example, that of the High Table, reinforced its members' feelings of belonging to the same community. This idea was emphasized by the former director of Makerere, who witnessed these transformations:

Friends at home tell me that academic dress such as ours was irrational and so it is. The students wanted it, felt the better for it and perhaps many needed all the boosts they could get to their self-confidence. They needed recognition. ${ }^{28}$

The reproduction of British university rites and traditions that permeate college life helped to create social practices and imaginaries, contributing to the identity of the community, while initiating young Africans into Western codes of appropriate behavior and respectability. At the first ball in 1947, students were expected to follow a painstaking protocol before and after each dance: engaging in pleasant conversation with their

27 "We build for the future," KNA, Nairobi, MAA/8/140, A. G. Macpherson, 1 July $1952,3$.

${ }^{28}$ Bernard de Busen, Adventures in Education (London: Titus Wilson Kendal, 1995), 93. 
partners and being sure to accompany them back to their seats once the dance was over. The creation in 1949 of an association of former students fostered the Makerereans' esprit de corps, long after they had left the college and abandoned the practice of Lunamakerere. ${ }^{29}$

These university practices, drawing upon a range of ancient European traditions, and incorporating codes of Englishness, contributed to the fabric of imperial academic communities. Indeed, they provided models of behavior for the educated elites who were considered to be at the cutting edge of colonial modernization policies. In that, they can be seen as part of the neo-traditions identified by Ranger and Hobsbawm, the principal function of which was to restructure relations between the dominant and the dominated in periods of change. ${ }^{30}$ The first official reunion of former students was held in 1952 under the double patronage of His Majesty the Kabaka (King) and the governor of Uganda. In his closing speech, the Kabaka stressed the universal nature of university communities, notably, in comparing Makerere with Cambridge, his alma mater, while the governor reminded the audience that Makerere remained, first and foremost, a colonial institution. ${ }^{31}$ This example illustrates the ambivalence of university reforms in a changing colonial context. The Asquith universities, to which Makerere was attached were, indeed, based on a narrow European centrism, as Eric Ashby reminds us:

The doctrine was a vivid expression of British cultural parochialism: its basic assumption was that a university system appropriate for Europeans brought up in London and Manchester and Hull was also appropriate for Africans brought up in Lagos and Kumasi and Kampala. ${ }^{32}$

Yet the acculturation of African elites did not stop at the borders of colonies; it continued in Great Britain, as the way of handling scholarship students demonstrates.

\footnotetext{
${ }^{29}$ Name attributed to Daniel Wako who studied the specifics of this university slang. Macpherson, They Built for the Future, 168.

${ }^{30}$ Eric Hobsbawm and Terence Ranger (eds.), The Invention of Tradition (Cambridge: Cambridge University Press, 2006).

${ }^{31}$ KNA, Nairobi, ED/1/2317. Newsletter, ${ }^{\circ} 10,10$ September 1952.

${ }^{32}$ Eric X. Ashby, African Universities and Western Tradition (London: Oxford University Press, 1964), 19.
} 


\section{Integrating, Supporting, and Controlling Colonial Students in Great Britain}

The creation in February 1942 of the post of Director of Colonial Scholars and Advisor to Colonial Students, followed in November by the designation of an Advisory Committee on the Welfare of Colonial People in the United Kingdom, demonstrates the attention given by the Colonial Office to welcoming and integrating colonial students to Great Britain. ${ }^{33}$ Faced with the church's vague desire to extend its educational mission in the home country and to continue to exercise its moral authority over the educated and Christianized elites, such initiatives allowed it to reaffirm direct responsibility for the British administration of colonial students. ${ }^{34}$ One of the principal issues of these training programs was specifically to keep educated elites within the imperial fold.

After the war, the influx of colonial students, whose numbers grew from 1000 to 5000 between 1945 and $1951,{ }^{35}$ led to the Director of Colonial Scholars and Advisor to Colonial Students delegating some responsibilities to the British Council. Thus, in 1950, agents of the British Council welcomed more than 1700 colonial students to Great Britain. At that time, there were 2000 colonial students present in London and its surroundings and 2200 in the provinces; of this number, 750 were not scholarship recipients. Besides welcoming students at the airport, the British Council offered training sessions to familiarize newcomers with daily life in Great Britain. These included visits to stores, restaurants, the underground, etc. ${ }^{36}$ Prior to their departure, preparation sessions were sometimes organized by local branches of the British Council who also distributed a regularly updated brochure entitled How to Live in Britain. Thus, in 1951, 17 Kenyans participated in a three-day training program in Nairobi during which former students came to talk about their experiences. Some were occasionally invited to stay with a

${ }^{33}$ PRO, London. CO/876/21. Welfare of Colonial Students in the UK, 1942-1943; London School of Economics (LSE), London. Archives of A. Carr-Saunders, B/3/12, n²6, J. L. Keith, 29 November 1943.

${ }^{34}$ Church of England Record Center, London. MC/AAC/1. AAC meeting, 3 July 1942.

${ }^{35} \mathrm{PRO}$, London. CO/1028/12. Conference of Voluntary Societies on the Welfare of Colonial Students in London: Appendix A, 1952.

${ }^{36}$ PRO, London. CO/876/265. British Council Report on the Welfare of Students, September 1950, 6 . 
British family to prepare themselves for their new way of life. ${ }^{37}$ These initiatives were designed to give newcomers a positive image of Great Britain and the British:

The first impressions which colonial students have formed on arrival in this country have often, in the past, been of bewilderment and discouragement, and sometimes of resentment at the apparent unfriendliness of their reception. ${ }^{38}$

The social fund (Amenity Fund), created in 1947, also aimed to enrich the student experience in Great Britain. The pro-rata contribution of each colony, according to the number of students it had in the United Kingdom, allowed for subsidies to clubs and associations offering colonial students recreational and cultural activities. These measures were designed to encourage immersion in British society, while both providing support and orienting leisure time toward what were considered useful activities. The Victoria League and Christian organizations, such as the YMCA and the YWCA, for example, proposed cultural outings (visits to Eton and Windsor), as well as recreational activities: Saturday evening dances, study groups, weekly meetings, etc. Training sessions were also offered to students during their holidays around carefully chosen themes such as "local government" or "England and the British." The Amenity Fund also contributed to financing holiday camps organized by the Workers' Educational Association (WEA). ${ }^{39}$ All these initiatives had the same goal: to promote the image of the Empire to new colonial elites. Actually, colonial students faced countless difficulties during their stay in Great Britain. Finding lodgings was frequently a serious challenge in light of the housing shortage and persistent racial prejudice.

\section{Distinguishing Colonial Students from the Immigrant Population}

Ideally, colonial students were placed in the traditional residential colleges of Oxford, Cambridge, Saint Andrews, Durham, Aberdeen, Exeter, or Cardiff, to both steep them in British culture and allow them to

\footnotetext{
${ }^{37}$ KNA, Nairobi. CNC/8/42. British Council Report on the Welfare of Students, May 1952.

${ }^{38}$ PRO, London. BW/3/25. Colonial Students in Britain, PEP Report, $9 / 12$ 1954, 3.

${ }^{39}$ PRO, London. CO/876/72. Arthur Creech Jones to J. L. Keith, 26 June 1946.
} 
benefit from a stimulating academic environment, while sparing them the temptations of the big cities. ${ }^{40}$ Nevertheless, since the capacity of these establishments was limited, in 1952, most colonial students still ended up in London, where they had the greatest difficulty finding lodgings. With insufficient resources, students often found themselves in farflung and notorious neighborhoods, such as Camden Town or Morning Crescent in London. ${ }^{4}$ The Colonial Office considered this situation dangerous and alarming:

The present housing shortage, coupled with the prejudice of the public against giving accommodation to Africans, constitutes the root of the trouble. This is accentuated by the rather exacting demand from the Africans. It is apparent, however, that whatever the cause of the trouble, if steps are not taken quickly to remedy it, there may be serious repercussions as a result of the Africans becoming disillusioned. ${ }^{42}$

To address these problems, a five-year program of construction and renovation of London, Edinburgh, and Newcastle residences-up to that point reserved for colonial students-was launched in 1951, thanks to a subsidy of $£ 450,000$ from the Colonial Development and Welfare Fund. ${ }^{43}$ The new residences were intended for temporary stays by both British and colonial students. Indeed, the objective was to encourage the formation of contacts, intermingling, and the integration of students within the same community, following the model of classic university colleges, and suppressing the racial and colonial characteristics of such residences. The temporary closing of former residences in London (Crescent Hall), Edinburgh, and Newcastle, where 460 students were lodged, caused grave concern among colonial students who were afraid of not finding any accommodation or suffering rental increases. ${ }^{44}$ Approximately thirty of them refused to leave the residence of Crescent

${ }^{40}$ PRO, London. BW/3/25. Colonial Students in Britain, PEP report, 1954, 9.

${ }^{41}$ PRO, London. CO/537/2574. J. L. Keith, Colonial Students in the UK and Eire, 25 February 1948.

${ }^{42}$ PRO, London. CO/876/69. Welfare of Colonial People on UK Advisory Council, $1944-46$.

${ }^{43}$ Ade Ajayi, The African Experience with Higher Education (London: James Currey, 1996), 154.

${ }^{44}$ PRO, London. CO/876/240. Parliamentary debate, 19 July 1950. 
Hall in July 1951, despite threats to cancel their scholarships. ${ }^{45}$ The event, covered extensively in the colonies' newspapers, was perceived as a form of collective student mobilization. ${ }^{46}$ Eventually, a consultative committee was established to coordinate the action of associations, universities, and the British Council on the question of student housing. ${ }^{47}$

Despite these initiatives and efforts conducted by the British Council's Accommodation Unit to identify private lodgings and convince owners to rent to colonial students at reasonable prices, ${ }^{48}$ the latter always faced the same racial prejudices. The influx of colonial people (who had come to participate in the war effort) to the big cities had reinforced racist sentiment among some of the British population. The students suffered from the same bullying and other expressions of suspicion and hostility as the rest of the colonial population, and had to submit to the color bar that was in effect in certain public places (hotels, restaurants, and stores). ${ }^{49}$ The Colour Bar Bill, condemning all forms of racial discrimination as well as authors of racist acts, tabled by Labour Member of Parliament Sorenson, was rejected in the spring of 1951, despite receiving support from the West African Students' Union (WASU) and the League of Colored People (LCP), both having denounced similar situations for many years. ${ }^{50}$

However, a number of the Colonial Office reports had identified rising racism in Great Britain and the threat this posed to its colonial policy, especially with regard to colonial students. They underlined the risk of students succumbing to communist anticolonial propaganda and engaging in activities considered undesirable. ${ }^{51}$ Failing to eliminate

${ }^{45}$ PRO, London. CO/876/265.

${ }^{46}$ Faced with the influx of students, provincial centers finally remained open and the construction of a new 200-bed residence was initiated in London, thanks to a subsidy of $£ 85,000$ from the CDWA.

${ }^{47} \mathrm{PRO}$, London. CO/1028/28. Consultative Committee on Welfare of Students, $1952-1953$.

${ }^{48}$ PRO, London. CO/876/265. Welfare Department, Report on Student Accommodations, 8 .

${ }^{49}$ KNA, Nairobi. ED/3/3161. A Bow Group Pamphlet, Coloured People in Britain, November 1952.

${ }^{50}$ PRO, London. CO/876/197. Colour Prejudice in the UK.

${ }^{51}$ PRO, London. BW/3/25. Colonial Students in Britain, PEP Report, 1954; PRO, London. CO/876/252. Interdepartmental committee on Welfare of Colonial People, The Coloured Population of London. 
racial prejudices, the British authorities specifically focused on colonial students, distinguishing them from the rest of the immigrant population. For example, the brochure, An Appeal to Londoners, encouraged Londoners to establish personal contacts with colonial students. In 1955, 3500 booklets entitled Far from home: Overseas students in London were distributed by various associations to inhabitants of the capital.

In total, numerous acculturation efforts, undertaken jointly by the colonies and home country, reveal the mechanisms and limitations of the social engineering accompanying post-war training programs. Clearly, the entire new British imperial project was based on the capacity to create fresh links between its different territories, for which students immersed in British culture were planned as flag-bearers. In the post-war context, when British leadership was being seriously questioned by both emerging powers and nationalist movements in the colonies, convincing the educated elites of the legitimacy of the Empire, making sure they would become lasting allies, seemed an eminently political undertaking.

\section{Training Allies-Academic Communities Serving The New British Imperial Project}

The assumptions underlying these training programs, the spectrum of activity of which extended significantly beyond merely the academic field, are clearly political. In offering colonial students as many opportunities as possible to absorb British culture, as well as excellent study conditions in both the colonies and the United Kingdom, the Colonial Office hoped to favorably carve relations that future ruling elites would nurture and, above all, that would divert them from the anticolonial ideologies that existed after the war. However, numerous obstacles encountered along the way revealed flaws in the new British imperial project.

\section{The Specter of Communism}

The African elites' possible acceptance of the anti-racist and anticolonial discourse of the Communist International was one of the obsessions of imperial powers. In January 1948, the Colonial Office brought together a working group to investigate the degree of political commitment of colonial students in Great Britain, in particular considering their receptivity to communist propaganda seeking to exploit their discontent 
and anti-British sentiment. With fewer than 12 students being official Communist Party members, of the 3200 colonial students at that time present in Great Britain, such fears were the product of rumor and fantasy. ${ }^{52}$ Nonetheless, in 1949 the government of Kenya decided to investigate the apparently suspicious political activities of the son of a chief, Charles Njonjo, then a law student in London. The inquiry finally revealed that such fears were baseless. ${ }^{53}$

Like other political groups based in the home country, the Communist Party organized political clubs and offered summer university programs, open to colonial students. ${ }^{54}$ Close to certain student organizations, like WASU, ${ }^{55}$ at times it also organized lectures, such as those held in London on the 2nd and 3rd of October 1948, entitled The Crisis of British Imperialism. In addition, the Monthly Colonial Socials, organized by activists, allowed for exchanges and informal contacts with British members.

The risk of politicization of colonial students stemmed more from their disappointment with respect to the colonial policy of the Labour Party. Nonetheless, the government did all in its power to organize propaganda efforts through clubs, discussion forums in certain universities, films, or most commonly the presentation of lectures on its imperial policy in student residences in London. It even arranged meetings between students and government-associated agents. On the left, the Fabian Colonial Bureau, founded in 1940 within the Fabian Society by individuals close to the Labour Party, provided colonial students many opportunities for dialogue and expression. ${ }^{56}$ For its part, the Independent Labour Party of Fenner Brockway echoed colonial students' claims in public and Parliament. Long considered the party of the Empire, Conservative Party authorities also sought to rehabilitate their negative image among colonial students. The Conservative Commonwealth Council organized political debates with students on the future of their colonial territories and on their associated problems. Picking up again on the previous

\footnotetext{
${ }^{52}$ Rhodes House Library, Oxford. Mss Brit EMP.s. 468. 725/1. Colonial Student Political Problems, Confidential Note, 1948.

${ }^{53}$ PRO, London. CO/537/4312, J. L. Keith to Ph. Mitchell, 11 February 1949.

${ }^{54}$ PRO, London. BW/3/25. Colonial Students in Britain, PEP Report, 1954, 12.

${ }^{55}$ PRO, London. CO/537/4312. Communist Influences Amongst Students in the UK, 1948.

${ }^{56}$ Ajayi, The African Experience, 141.
} 
government's rhetoric on the new Empire, in one of its pamphlets published in 1952, the Bow Group, founded in 1951 by Conservative students, castigated the racism of colonial emigrants and officers:

The emigrant who plays the petty aristocrat, the Colonial Office official who makes up for any social inferiority experienced at home by a good dose of colour consciousness in the colonies; all these and worse have, in the mind of the coloured man, been connected with Conservatism. ${ }^{57}$

\section{Highly Sought-After Colonial Elites}

Various British political organizations attempted to seduce colonial students to keep future African ruling elites in the imperial fold when other powers were trying to weigh in on the political future of the colonial territories.

The Eastern Bloc, from the end of the 1940s, had established scholarship programs for colonial students. Thus, Czechoslovakia had welcomed 70 West African students in 1949 and the movement continued throughout the following decades. ${ }^{58}$ Also, immediately after the war, the United States consolidated its tradition of welcoming colonial students to its universities. In the 1930s, a number of West African nationalist leaders, such as Kwame Nkrumah and Nnamdi Azikiwe, were trained in the United States. In 1948, 154 African students were studying in the United States, of whom 103 came from British colonies-twice the number in 1946, thanks to various scholarship programs offered by the government (Fulbright), private philanthropic foundations (Ford, Carnegie Corporation, and the Phelps Stokes Fund), and AfricanAmerican colleges and churches. These different scholarships, administered by the Institute of International Education (IIE), permitted 22 Kenyans to study in the United States between 1948 and $1953 .{ }^{59}$

\footnotetext{
${ }^{57}$ KNA, Nairobi. ED/3/3161. A Bow Group Pamphlet, 11.

${ }^{58}$ PRO, London. CO/537/4312, 20 July 1949.
}

${ }^{59}$ Kenneth King, Panafricanism and Education: A Study of Race Philanthropy and Education in the Southern States of America and East Africa (Oxford: Clarendon Press, 1971); Ade Ajayi, The American Factor in the Development of Higher Education in Africa (Los Angeles: University of California, 1988); John C. Stoner, "Anti-communism, Anticolonialism and African Labor, the AFL-CIO, 1955-1975," Ph.D. thesis, Columbia University, 2000; Charton, La naissance ambigüe; Robert F. Stephens, Kenyan Student 
Great Britain closely followed these initiatives and, in 1947, named a Colonial Attaché to the British Embassy in Washington to support colonial students, that is, the British Information Service (BIS), created the previous year, tasked to disseminate British colonial propaganda on American soil. However, despite its efforts, London did not manage to take control of the Committee on Africans studying in North America (CASNA), created in 1946 to coordinate the actions of the Colonial Office, colonial governments, and American organizations interested in colonial students in America. In 1949, its activities were attached to the IIE, which fulfilled the same welcoming and information missions for colonial students in the United States as did the British Council in Great Britain. ${ }^{60}$ From 1945 onward, the institute published and distributed an information guide for foreign students entitled: Meet the US, Handbook for Foreign Students and Specialists.

Colonial students were also of interest to newly independent countries like India. From 1947 onward, this young republic offered 70 scholarships to students from Commonwealth and British colonies, 30 of which were reserved for students of Indian origin and four for students from East African colonies. Thus, this new state intended to affirm its role as a role model and leader in the fight for the national liberation of countries still under colonial domination, while claiming a central place within the new Commonwealth.

The British authorities did not look at all kindly upon such initiatives since they were in direct competition with their own strategies for controlling and integrating colonial students. ${ }^{61}$ They also had to deal with resistance from some colonial governments that were trying to obstruct the implementation of modernization programs.

Airlifts to America 1959-1961: An Educational Odyssey (Nairobi: East African Publishers, 2013).

${ }^{60}$ Columbia University, Special collections, Archives of the Carnegie Corporation, Box 117, 10 January 1947, and note of 3 November 1949.

${ }^{61}$ PRO, London. CO/537/3646. Report of the Information Services of Kenya, November 1948. 


\section{Colonial Resistance}

The reforms imposed by London, were received with considerable reluctance in Kenya, where the government strove to slow them or bypass them altogether. This was symptomatic of the dissonance between the reform-minded pragmatism of "War Time babies," based in London, and followers of an archaic colonial order that needed to be sacrificed to save the Empire. The historian Ronald Hyam interpreted this hiatus as a major factor in the fall of the British Empire. ${ }^{62}$

The Kenyan government rejected the global schedule suggested for these reforms, pleading that reforms should follow at the pace most suitable to each territory. For instance, the secretariat of the colony reminded everyone that, while certain families in West Africa already comprised (in 1944) three generations of graduates, the education of those in East Africa was only in its infancy. Makerere's changeover to a university was also vehemently denounced by the Kenyan Director of Education, who regretted the loss of the former professional school and deplored the development of general training when the colony, first and foremost, needed doctors, assistant veterinarians, and teachers. ${ }^{63}$ All these criticisms were actually nurtured by the severe racism of a colonial order guaranteeing white hegemony that felt threatened by modernization projects. The Governor of Kenya, Sir Philip Mitchell, who had already served 37 years in the colonies, expressed the same feeling when he stated:

Instead of facing the unhappy but at present undeniable facts of African dishonesty, unreliability, untruthfulness and sloth which are to-day among the major-perhaps they are the major-difficulties which confront us in Kenya, a pathetic and romantic picture is conjured out of the writers imaginations. ${ }^{64}$

The Principal of the Alliance High School (AHS), the main high school in Kenya, where the vast majority of Kenyan students were trained, never missed an opportunity to castigate the academic reforms designed in London. Carrey Francis virulently denounced the ambitions

${ }^{62}$ Ronald Hyam, Britain's Declining Empire: The Road to Decolonisation, 1918-1968 (Cambridge: Cambridge University Press, 2006).

${ }^{63}$ KNA, Nairobi. ED/3/3181, 6 March 1944.

${ }^{64}$ PRO, London. CO/859/171/1, 19 May 1949. 
of Makerere university which, in his view, inflated student pride and undermined the entire enterprise of colonial education in Kenya that he was promoting, which was based on obedience and submission to a basically racist colonial order. In his judgment, the team of young inexperienced teachers recruited for Makerere, without knowing anything of the realities of East Africa, encouraged dangerous practices, almost debauchery (e.g., in occasionally proposing a drop of sherry to students, which was a common practice in Great Britain at the time) ${ }^{65}$ Refusing to consider the Africans as anything other than big school children, he could not accept that students at Makerere should be treated like British undergraduates. In fact, African teachers at AHS were paid one quarter the salary accorded their European colleagues, while trousers and shoes were banned in the name of preservation of traditional lifestyles. As for studies in Great Britain, he considered them both inappropriate and dangerous:

The best educated Africans in Kenya-those who have obtained school certificates and especially those who have studied at Makerere-are seldom doing real work. This is to be deplored. The chief reason is that these men, instead of getting down to work, go to continual "courses" overseas. When one course is completed, they ask for another. Some courses are unsuitable, a waste of time or worse, a very great waste of money; because of them, men are kept from, and sometimes incapacitated for, the plain ordinary jobs which they might have done, and which so greatly need to be done. I know of no one who has clearly benefited from an overseas course. Some have clearly been harmed, some ruined. Even those who are unsuccessful in getting overseas are damaged; they long to go and their minds are taken from their work. ${ }^{66}$

These lines reveal how much this perspective, steeped in the racist paternalism of Carey Francis, who for over twenty years, trained the educated elite of the colony, was so far removed from approaches underpinning modernization programs. Unable to block them, the colonial authorities tried to bypass them, by controlling the activities of students in the home country.

${ }^{65} \mathrm{KNA}$, Nairobi. CNC/7/257. Higher Education for Non-European Students in East Africa, 28 August 1948.

${ }^{66}$ KNA, Nairobi. ED/1/2743, 30 December 1953. 
Worried about the living and studying conditions of African students, and more specifically about the "bad influences" to which they might be exposed, the Government of Kenya soon asked for the creation of a position of Supervisor of African Bursars. ${ }^{67}$ The Colonial Office rejected such a demand based on racial distinctions, and suggested naming a liaison agent (following the example of the Gold Coast and Nigeria since 1946$)^{68}$ for all students from East Africa. The officer in charge was chosen for his good knowledge of Kenya's social environment and his capacity to defend colonial interests against the Colonial Office, all while being capable of gaining the confidence of students, so as to exercise a "positive influence" over them. The liaison officer was actually caught between the contradictory requirements of the colonial government and the Colonial Office. He was to submit quarterly reports to colonial authorities about student progress and lifestyle as well as the company students kept, and was encouraged to make regular contact with them. For students, he represented merely a spying government agent; one of them frankly told him that there was something sinister about his job. 69

Despite all the Colonial Office's efforts, colonial racism sometimes expressed itself in the home country, for example, during the inauguration, accompanied by great fanfare, of East African House in London in 1951. This club was in fact very restricted, at the time having only 6 Africans amongst its 720 mostly European members. ${ }^{70}$ For African students, it was hard to differentiate between the policies of colonial governments and those of the Colonial Office. In their publications, members of the Kenya African Students Association continuously denounced the violent repression of the Mau Mau in Kenya during its state of emergency and, especially, the propaganda disseminated to justify such violence. ${ }^{71}$ Examples from the Gold Coast, Malaysia, and Kenya all demonstrated the same degree of brutality, and were actually underscoring the schizophrenic nature of the modernization policies of the British Empire.

${ }^{67}$ PRO, London. CO/537/4270, 6 April 1949.

${ }^{68}$ PRO, London. CO/537/1222.

${ }^{69}$ PRO, London. CO/537/4270, March 1949.

${ }^{70}$ KNA, Nairobi. ED/1/2297, 20 July 1951.

${ }^{71}$ KNA, Nairobi. ED/1/2295, October 1955. 


\section{CONCLUSION}

Higher education programs, which were thought of as imperial modernization instruments, certainly contributed to the creation of an educated African elite. However, they seemed to have failed to bring together an imperial community, embodied in these new elites. When they returned to Kenya, students confronted the inertia and racism of a conservative colonial society. They were also sometimes cruelly faced with direct competition from a new wave of expatriates sent to the colonies to implement social and economic modernization programs. Thus, the number of Europeans established in Kenya rose from 30,000 to 50,000 between 1948 and 1952. These employees were hired by international companies or by the administration, and occupied posts that should have theoretically been available to the new African educated elites. Such a situation accentuated the pressure on an already tight labor market.

Above all, such programs revealed the limitations and paradoxes of post-war modernization policies. The persistence of racial hierarchies and differentiated treatment in certain colonies like Kenya, stemming from unabashed racist paternalism, contradicted the spirit of post-war reforms. Indeed, these voluntarist programs aimed to put a new face on the Empire, backed by a community of interests, of history, and of values which would relegate racial distinctions to the backburner, and for which the educated Africans, emblematic figures of this modernity, were to spearhead. The mitigated success of these reforms, contested on all fronts, ultimately revealed that it was certainly easier to reform the idea of the Empire than to reform the Empire itself.

\section{BIBLIOGRAPHY}

Adi, Hakim. West Africans in Britain 1900-1960, Nationalism, Panafricanism and Communism. London: Lawrence and Wishart, 1998.

Ajayi, Ade J. F. The American Factor in the Development of Higher Education in Africa. Los Angeles: University of California, 1988.

. The African Experience with Higher Education. London: James Currey, 1996.

Ashby, Eric X. African Universities and Western Tradition. London: Oxford University Press, 1964.

- British, Indians, African Universities: A Study in the Ecology of Higher Education. London: Weidenfeld and Nicolson, 1966. 
Awenengo Dalberto, Séverine, Hélène Charton, and Odile Goerg. "Urban Planning, Housing, and the Making of 'Responsible Citizens' in the Late Colonial Period: Dakar, Nairobi, Conakry." In Governing Cities in Africa: Politics and Policies, edited by Simon Becker and Laurent Fourchard, 43-64. Cape Town: HSRC Press, 2013.

Bartenev, Vladimir. “L'URSS et l'Afrique noire sous Khrouchtchev: la mise à jour des mythes de la coopération." Outre-mers 354-355 (2007): 63-82.

Barthélémy, Pascale. Africaines et diplômées à l'époque coloniale (1918-1957). Rennes: Presses universitaires de Rennes, 2010.

Charton, Hélène. "La genèse ambiguë de l'élite kenyane, origine, formation et intégration, de 1945 à l'indépendance." Ph.D. dissertation, Université Paris 7-Denis Diderot, 2002.

—. "Homo Africanus academicus. Les limites de la fabrique d'une élite universitaire africaine en Afrique de l'Est." Outre-Mers, Revue d'histoire 394-395 (2017): 127-148.

—. "Produits d'Empires: expériences universitaires coloniales britanniques et françaises en Asie et en Afrique aux XIX et XX ${ }^{\mathrm{e}}$ siècles." Outre-Mers, Revue d'histoire 394-395 (2017): 5-13.

Cooper, Frederick. Decolonization and African Society: The Labour Question in French and British Africa. Cambridge: Cambridge University Press, 1996.

- Colonialism in Question: Theory, Knowledge, History. Berkeley: University of California Press, 2005.

- Citizenship Between Empire and Nation. Princeton: Princeton University Press, 2014.

Darwin, John. The Empire Project: The Rise and Fall of the British World System, 1830-1970. Cambridge: Cambridge University Press, 2009.

de Busen, Bernard. Adventures in Education. London: Titus Wilson Kendal, 1995.

de Saint Martin, Monique, Grazia Scarfò Ghellab, and Kamal Mellakh (dir.). Étudier à l'Est. Expériences de diplômés africains. Paris: Karthala, 2015.

Gifford, Posser, and William Roger Louis, eds. The Transfer of Power in Africa: Decolonization 1940-1960. Harvard: Harvard University Press, 1982.

Goodman, Joyce, Gary McCulloch, and William Richardson. "Empires Overseas' and 'Empires at Home' Postcolonial and Transnational Perspectives on Social Change in the History of Education." Paedagogica Historica 45 (2009): 695-706.

Hall, Catherine. Cultures of Empire: Colonizers in Britain and the Empire in the Nineteenth and Twentieth Centuries: A Reader. Manchester: Manchester University Press, 2000.

Hall, Catherine, and Sonya O. Rose, eds. At Home with the Empire: Metropolitan Culture and the Imperial World. Cambridge: Cambridge University Press, 2006. 
Hargreaves, John D. "The Idea of a Colonial University." African Affairs 72 (1973): 26-36.

Hobsbawm, Eric, and Terence Ranger, eds. The Invention of Tradition. Cambridge: Cambridge University Press, 2006.

Hyam, Ronald. Britain's Declining Empire: The Road to Decolonisation, 1918-1968. Cambridge: Cambridge University Press, 2006.

Kallaway, Peter, and Rebecca Swartz, eds. Empire and Education: The Shaping of a Comparative Perspective. New York: Peter Lang, 2016.

Kastakioris, Constantin. "Transferts Est-Sud. Échanges éducatifs et formation de cadres africains en Union soviétique pendant les années soixante." Outre-mers 354-355 (2007): 83-106.

King, Kenneth. Panafricanism and Education: A Study of Race Philanthropy and Education in the Southern States of America and East Africa. Oxford: Clarendon Press, 1971.

Leney, Katia. Decolonisation, Independence and the Politics of Higher Education in West Africa. London: Edwin Mellen Press, 2003.

Lewis, Johanna. Empire State Building: War and Welfare in Kenya 1925-52. Oxford: James Currey, 2000.

Louis, William Roger. "American Anti-colonialism and the Dissolution of the British Empire." International Affairs 61, no. 3 (1985): 395-420.

Macpherson, Margaret. They Built for the Future: A Chronicle of Makerere College 1922-1962. Cambridge: Cambridge University Press, 1964.

Mangan, James Anthony, ed. Benefits Bestowed, Education and British Imperialism. Manchester: Manchester University Press, 1988.

Michel, Marc. Décolonisations et émergence du tiers-monde. Paris: Hachette, 1993.

Nwauwa, Apollo O. Imperialism, Academe and Nationalism: Britain and University Education for Africans 1860-1960. London: Frank Cass, 1997.

Olusanya, Gabriel Olakunle. The West African Students Union and the Politics of Decolonization, 1935-1958. Ibadan: Daystar Press, 1982.

Pietsch, Tamson. Empire of Scholars, Universities, Networks and the British Academic World (1850-1939). Manchester: Manchester University Press, 2013.

Sicherman, Carol. Becoming an African University. Makerere 1922-2000. Trenton: Africa World Press, 2005.

Stephens, Robert F. Kenyan Student Airlifts to America 1959-1961: An Educational Odyssey. Nairobi: East African publishers, 2013.

Stoler, Ann Laura, and Frederick Cooper, eds. Tensions of Empire: Colonial Cultures in a Bourgeois World. Berkeley: California Press, 1997.

Stoner, John C. "Anti-communism, Anti-colonialism and African Labor, the AFL-CIO, 1955-1975.” Ph.D. dissertation, Columbia University, 2000.

Westad, Ode Arne. The Global Cold War: Third World Interventions and the Making of Our Times. New York: Cambridge University Press, 2005.

Yengo, Patrice, and Monique de Saint-Martin. "Quelles contributions des élites 'rouges' au façonnement des États post-coloniaux?” 226 (2017): 231-258. 
Open Access This chapter is licensed under the terms of the Creative Commons Attribution 4.0 International License (http://creativecommons.org/licenses/ by $/ 4.0 /)$, which permits use, sharing, adaptation, distribution and reproduction in any medium or format, as long as you give appropriate credit to the original author(s) and the source, provide a link to the Creative Commons license and indicate if changes were made.

The images or other third party material in this chapter are included in the chapter's Creative Commons license, unless indicated otherwise in a credit line to the material. If material is not included in the chapter's Creative Commons license and your intended use is not permitted by statutory regulation or exceeds the permitted use, you will need to obtain permission directly from the copyright holder.

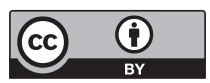

